\title{
APLIKASI METODE SINGULAR SPECTRAL ANALYSIS (SSA) DALAM PERAMALAN PERTUMBUHAN EKONOMI INDONESIA TAHUN 2017
}

\author{
Rina Sri Kalsum Siregar ${ }^{1}$, Dina Prariesa ${ }^{2}$, Gumgum Darmawan ${ }^{3}$ \\ Magister Statistika Terapan, Universitas Padjajaran, Jl. Dipati Ukur No.35, Bandung 40132 \\ Email: rienhaaa@gmail.com ${ }^{1}$, dinaprariesa @gmail.com ${ }^{2}$, gumstat @gmail.com ${ }^{3}$
}

\begin{abstract}
Abstrak
Tujuan dari penelitian ini adalah untuk melihat pola musiman pada data Produk Domestik Bruto (PDB) riil Triwulanan Tahun 2000-2016 dan melihat penerapan dari Singular Spectral Analysis (SSA) pada data PDB tersebut untuk meramal data PDB pada tahun 2017. Adapun metode SSA yang digunakan adalah metode recurrent forecasting dengan bootstrap confidence interval untuk melihat selang kepercayaannya. Sumber data berasal dari data PDB tahun 2000-2016 tahun dasar 2000 yang dikumpulkan oleh Badan Pusat Statistik (BPS). Hasilnya menunjukkan bahwa metode SSA dapat dijadikan metode yang handal dan dapat dikatakan valid dilihat dari nilai ukuran MAPE 0.82 dan ukuran tracking signal sebesar -4.00 .
\end{abstract}

Kata Kunci: Produk Domestik Bruto, Metode Singular Spectral Analysis, Peramalan

\begin{abstract}
The purpose of this study was to look at seasonal patterns in the data of Gross Domestic Product (GDP) quarterly in the year 2000-2016 and the implementation of Singular Spectral Analysis (SSA) in the data of GDP to predict the data of GDP in 2017. The SSA method used is the method of recurrent forecasting with bootstrap confidence interval to look at its beliefs of interval. The source of data derived from the data of GDP in 2000-2016 with the base year in 2000 compiled by the Central Statistics Agency (CSA). The results showed that the SSA method can be used as a reliable method and can be valid that view from the value of MAPE size is 0.82 and the size of the tracking signal at -4.00 .
\end{abstract}

Keywords: Gross Domestic Product, Singular Spectral Analysis Method, Forecasting

\section{Pendahuluan}

Pertumbuhan ekonomi merupakan perubahan aktifitas perekonomian dalam menghasilkan tambahan pendapatan masyarakat suatu Negara secara berkesinambungan selama periode tertentu. Selain itu, pertumbuhan ekonomi juga dapat dikatakan salah satu indikator keberhasilan perekonomian suatu Negara [1]. Salah satu indikator penting untuk mengetahui kondisi ekonomi di suatu negara dalam suatu periode tertentu adalah data Produk Domestik Bruto (PDB), baik atas dasar harga berlaku maupun atas dasar harga konstan [2].

Pada dasarnya, PDB merupakan jumlah nilai tambah yang dihasilkan oleh seluruh unit usaha dalam suatu negara tertentu, atau merupakan jumlah nilai barang dan jasa akhir yang dihasilkan oleh seluruh unit ekonomi. PDB atas dasar harga berlaku menggambarkan nilai tambah barang dan jasa yang dihitung menggunakan harga yang berlaku pada setiap tahun, sedangkan PDB atas dasar harga konstan menunjukkan nilai tambah barang dan jasa tersebut yang dihitung menggunakan harga yang berlaku pada satu tahun tertentu sebagai dasar. PDB nominal (PDB atas dasar harga berlaku) merujuk kepada nilai PDB tanpa memperhatikan pengaruh harga, sedangkan PDB riil (PDB atas dasar harga konstan) mengoreksi PDB nominal dengan memasukkan pengaruh dari harga. PDB atas dasar harga berlaku dapat digunakan untuk melihat pergeseran dari struktur ekonomi, sedangkan PDB atas dasar harga konstan digunakan untuk 
mengetahui pertumbuhan perekonomian dari tahun ke tahun. Badan Pusat Statistik [2] dalam Berita Resmi Statistik menyatakan bahwa pertumbuhan ekonomi Indonesia pada tahun 2016 triwulan ke-2 adalah sebesar $5,18 \%$.

Peramalan (forecasting) dalam PDB rill (pertumbuhan ekonomi) menjadi suatu hal yang sangat penting untuk melihat bagaimana perkembangan PDB atau pertumbuhan ekonomi suatu negara, sehingga pemerintah dapat mengambil kebijakan yang perlu berdasarkan hasil yang didapat. Kegiatan peramalan merupakan bagian dari ilmu statistik dengan berbagai model yang ditawarkan, salah satunya Model Singular Spectrum Analysis (SSA) [3].

Beberapa hasil penelitian menunjukkan bahwa Model SSA memiliki beberapa keuntungan dibandingkan model time series yang lain, seperti ARIMA [4], [5], [6], [7], [8], [10], dan [13]. Keunggulan dari model SSA terlihat lebih fleksibel dan mampu memodelkan musiman dengan waktu multi periode dan musiman yang kompleks [6], [7], dan [8]. Selain itu, model SSA terhindar dari banyaknya syarat seperti independensi dan normalitas residual, sebagaimana pada model ARIMA [10] dan [13]. Suatu metode peramalan yang paling baik dapat di lihat dari nilai ukuran Mean Absolute Percentage Error (MAPE) yang kecil dan ukuran tracking signal pada batas yang dapat diterima [6], [7], [8], dan [11].

Berdasarkan penjelasan di atas, peneliti ingin melihat pola musiman atau tren pada data Produk Domestik Bruto (PDB) riil Triwulanan Tahun 20002016 dan menerapkan model SSA pada data tersebut untuk meramal data PDB riil pada tahun 2017. Selain itu, penelitian ini juga ingin melihat sejauh sejauh mana keunggulan model ini berdasarkan ukuran MAPE dan tracking signal-nya. Hasil peramalan data PDB 2017 menggunakan metode recurrent forecasting dibandingkan metode bootstrap forecasting dengan melihat selang kepercayaan.

\section{Metode Penelitian}

Metode penelitian yang digunakan dalam penelitian ini adalah analisis data statistik menggunakan Program R. Jenis penelitian ini merupakan jenis penelitian eksperimen dengan membandingkan 2 jenis metode analisis data statistik, yaitu metode recurrent forecasting dibandingkan metode bootstrap forecasting dengan melihat selang kepercayaan [14]. Data yang digunakan adalah data Produk Domestik Bruto Atas Dasar Harga Konstan (PDB ADHK/PDB Riil) deret berkala triwulanan dari tahun 2000-2016 dengan tahun dasar 2000, yang bersumber dari Badan Pusat Statistik
[8]. Analisis data PDB ADHK menggunakan metode SSA dan metode bootstrap forecasting.

\section{Hasil dan Pembahasan}

\subsection{Identifikasi Data PDB ADHK Triwulanan}

Data PDB triwulanan dianggap sangat baik untuk menggambarkan perkembangan perekonomian suatu negara atau wilayah. Analisis time series data PDB triwulan sangat penting peranannya untuk mengetahui perkembangan perekonomian suatu negara atau daerah dari waktu ke waktu dalam periode waktu yang relatif pendek, yakni 3 (tiga) bulan. Hasil analisis ini sangat efektif dalam mendukung proses penentuan arah kebijakan ekonomi suatu negara atau daerah tersebut dengan cepat.

PDB merupakan salah satu indikator untuk mengetahui kondisi perekonomian suatu negara. Jadi, kondisi perekonomian Indonesia dapat digambarkan melalui besarnya nilai PDB Indonesia pada suatu waktu. Secara umum, PDB Indonesia selalu mengikuti pola trend naik. Artinya, besarnya PDB Indonesia selalu mengalami pertumbuhan dari waktu ke waktu. Selain itu, juga terlihat adanya pola fluktuasi beraturan yang hampir selalu terjadi di setiap tahun. Hal ini merupakan indikator bahwa PDB Indonesia dipengaruhi oleh suatu pola musiman. Efek musiman terbesar rata-rata terjadi di setiap triwulan III. Jadi, setiap triwulan III terdapat fenomena yang menyebabkan angka PDB Indonesia lebih besar dibandingkan triwulan lainnya. Pola musiman yang terjadi di setiap tahun terlihat merupakan efek musiman aditif. Efek musiman aditif ini ditunjukkan dengan fluktuasi musiman dari tahun ke tahun yang besarnya hampir sama. Kondisi PDB atas dasar harga konstan dari tahun 2000 sampai tahun 2016 dengan Tahun Dasar 2000 dapat di lihat pada Gambar 1.

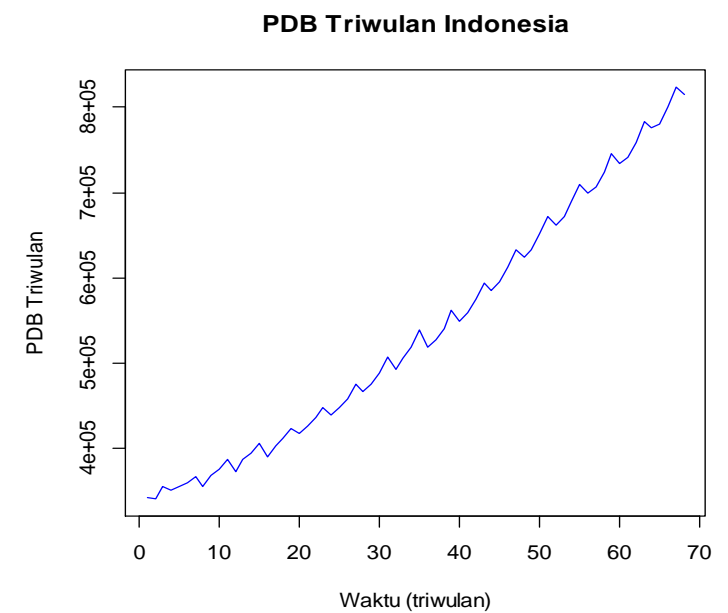

Gambar 1. PDB Atas Dasar Harga Konstan Tahun 2000-2016 Tahun Dasar 2000 
Perekonomian Indonesia tahun 2000-2016 ketika digambarkan melalui PDB triwulanan terlihat adanya fluktuasi-fluktuasi nilai PDB yang menunjukkan bahwa setiap triwulan terdapat perbedaan kondisi ekonomi yang cukup signifikan. Hal ini dikarenakan di setiap triwulan terdapat fenomena yang berbeda-beda yang mempengaruhi besarnaya nilai PDB setiap triwulan. Perbedaan fenomena yang berdampak pada nilai PDB inilah yang disebut dengan efek musiman. Dengan kata lain, fenomena musiman yang terjadi di setiap triwulan berbeda-beda. Untuk memastikan apakah PDB terpengaruh faktor musiman, dapat dilihat melalui hasil pengujian terhadap adanya efek musiman [3].

Pengujian adanya efek musiman ini menghasilkan fungsi 'Data Mengikuti Pola Musiman dengan periode 3.94'. Artinya data mempunyai pola musiman berulang dengan periode ulangan setiap 4 periode. Karena data PDB yang dihitung menggunakan data PDB triwulanan maka bisa diartikan perulangan pola musiman ini terjadi setiap triwulannya.

\subsection{Metode SSA pada Peramalan PDB ADHK Triwulanan}

Peramalan diperlukan untuk memperkirakan kejadian di masa yang akan datang [10]. Peramalan sangat membantu dalam kegiatan perencanaan dan pengambilan keputusan akan suatu kebijakan. Apalagi jika ada tuntutan untuk dapat mengambil kebijakan secara cepat yang menyangkut masa depan perekonomian suatu negara atau wilayah. Selain itu, peramalan dapat digunakan sebagai sarana antisipasi terhadap kejadian yang tidak diinginkan di periode mendatang. Dalam penelitian ini digunakan metode SSA untuk meramalkan PDB ADHK Triwulanan pada tahun mendatang dengan 2 tahapan besar, yaitu dekomposisi dan reconstruction.

\subsection{Dekomposisi}

Pada dekomposisi terdapat dua tahapan yaitu Embedding dan Singular Value Decomposition (SVD). Pada tahapan dekomposisi data dibagi menjadi data insample dan outsample dengan periode musiman 4 sesuai hasil pengujian sebelumnya. Parameter yang memiliki peran penting dalam dekomposisi adalah Window Length (L). Window Length (L) merupakan salah satu parameter utama dari SSA. Pada tahapan ini diperlukan penentuan parameter window length (L) dengan ketentuan $2<\mathrm{L}<\frac{N}{2}$. Namun untuk penentuan nilai window length tidak ada aturan yang baku sehingga pengulangan analisis SSA dengan berbagai nilai window length yang berbeda perlu dilakukan untuk mendapatkan model yang cocok. Pada penelitian ini window length yang diuji sebesar 34, 24, 14, 11, 9, 4, dan 2 yang menghasilkan nilai MAPE terkecil pada window length 9. Sehingga pada tahapan selanjutnya window length $(\mathrm{L})$ yang digunakan adalah $\mathrm{L}=9$.

\section{Embedding}

Langkah pertama dalam SSA adalah embedding dimana $\mathrm{F}$ ditransformasi ke dalam matriks lintasan berukuran L x K. Matriks lintasan ini merupakan matriks dimana semua elemen pada anti diagonalnya bernilai sama. Matriks lintasan tersebut dinamakan matriks Hankel dengan dimensi $\mathrm{L} \times \mathrm{K}$ dari data insample dengan $\mathrm{L}=9$ dan $\mathrm{K}=\mathrm{n} 1$ (jumlah sampel insample $)-\mathrm{L}+1=64-9+1=56$. Berikut ini merupakan matriks lintasan yang terbentuk.

$$
\mathbf{X}=\left(x_{i j}\right)_{i, j=1}^{9,56}
$$

dengan

$$
X_{i j}=\left[\begin{array}{cccc}
342.852,4 & 340.865,2 & \ldots & 699.526,3 \\
340.865,2 & 355.289,5 & \ldots & 705.934,3 \\
\vdots & \vdots & \ddots & \vdots \\
368.650,4 & 375.720,9 & \ldots & 775.447,1
\end{array}\right]
$$

\section{Singular Value Decomposition (SVD)}

Pada tahapan ini kita membuat Singular Value Decomposition dari matrik lintasan X. Matrik X terbentuk dari eigen vector $U_{i}$, singular value

$\sqrt{\lambda_{i}}$, dan principal component $V_{i}^{T}$. Ketiga elemen pembentuk SVD ini disebut dengan eigentriple. SVD dari matrik lintasan dapat didenotasikan sebagai berikut:

$$
\begin{aligned}
& X=X_{1}+X_{2}+\cdots+X_{d} \\
& =U_{1} \sqrt{\lambda_{1}} V_{1}^{T}+U_{2} \sqrt{\lambda_{2}} V_{2}^{T}+\cdots+U_{d} \sqrt{\lambda_{d}} V_{d}^{T} \\
& =\sum_{i=1}^{d} U_{i} \sqrt{\lambda_{i}} V_{i}^{T}
\end{aligned}
$$

Plot yang terbentuk dari eigen value dan eigen vectors pada window length 9 dapat dilihat pada Gambar 2. 

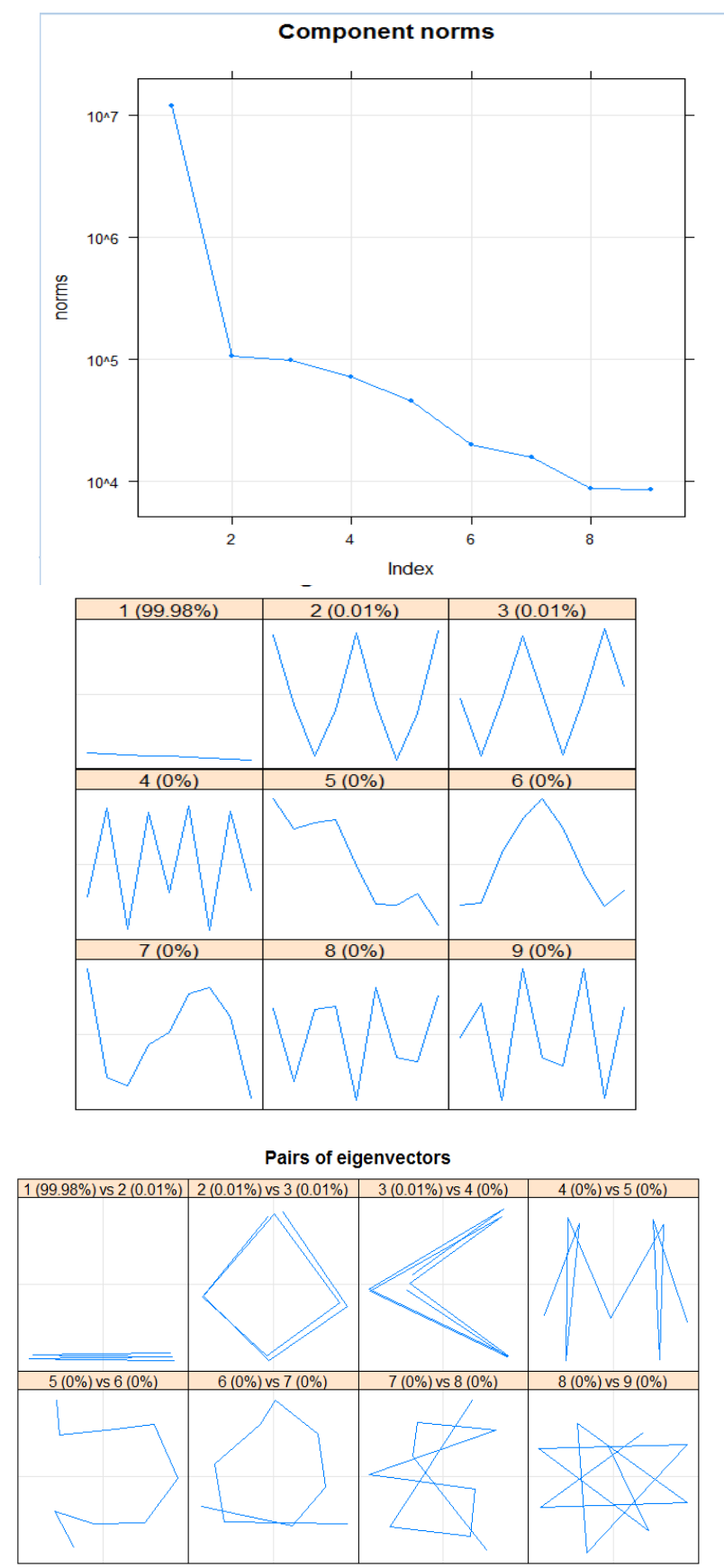

Gambar 2. Eigenvalue dan Eigenvectors $(\mathrm{L}=9)$

\subsection{Reconstruction}

Pada rekontruksi terdapat dua tahapan yaitu Grouping dan Diagonal Averaging. Parameter yang memiliki peranan penting dalam rekontruksi adalah grouping effect $(\mathrm{r})$. Tujuan dari tahapan grouping ini adalah memisahkan komponen aditif dari data deret waktu. Pada tahapan ini diputuskan pengelompokan yang sesuai dan bagaimana merekontruksinya. Dengan kata lain, diperlukan identifikasi eigentriples yang sesuai dengan data deret waktu yang diteliti. Terdapat dua cara dalam menentukan pengelompokan yang pertama yaitu dengan mengobservasi data deret waktu secara keseluruhan dan cara kedua yaitu mengeksplorasi periodogram deret waktu.

Dari pengelompokan eigenvalue dan eigenvector pada Gambar 2 dengan window length $\mathrm{L}$ $=9$, secara subjektif pada bagian pertama dapat dilihat terdapat 3 patahan kasar, pada bagian kedua juga terbentuk 3 macam bentuk eigenvector yang berbeda. Sehingga apabila dilakukan observasi data deret waktunya secara keseluruhan (cara 1) kelompok yang kita bentuk ada 3 macam. Kelompok pertama merupakan pengelompokan berdasarkan trend, sedangkan kelompok kedua dan ketiga merupakan pengelompokan berdasarkan musiman dengan periodogram yang berbeda.

Cara kedua yaitu mengeksplorasi periodegram deret waktu dan pengelompokan berdasarkan periodegram terdekat. Sebelum itu kita melakukan analisis komponen utama pada data eigenvalue untuk menentukan banyaknya komponen utama dan didapatkan output sebanyak 5 komponen utama (pada baris ke 5 diambil karena mampu menjelaskan sebanyak 99.99\%), seperti tampak pada Gambar 3.

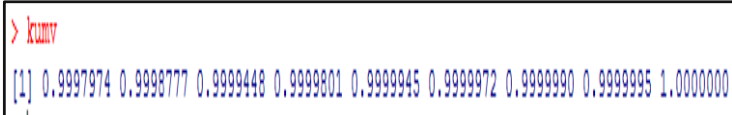

Gambar 3. Data Eigen Value

Kemudian kita melakukan pengujian periodegram pada matriks lintasan diambil 5 kolom pertama. Dari pengujian ini kita dapatkan 2 macam periode musiman sehingga data dapat kita kelompokkan menjadi 3 kelompok data trend, season 1 , dan season 2 .

1. Grouping

Berdasarkan penjelasan di atas kita membagi pengelompokan menjadi 3 macam yaitu trend, season 1, dan season 2. Dengan kelompok trend terdiri dari komponen utama 1 , kelompok season 2 terdiri dari komponen utama 2 dan 3 dan kelompok season 3 terdiri dari komponen utama 4 dan 5 dengan plot korelasi antar kelompok yang terbentuk dapat dilihat pada Gambar 4. Kita dapat melihat adanya strong separability saat masing masing kelompok tidak lagi berkorelasi, seperti tampak pada Gambar 4. 


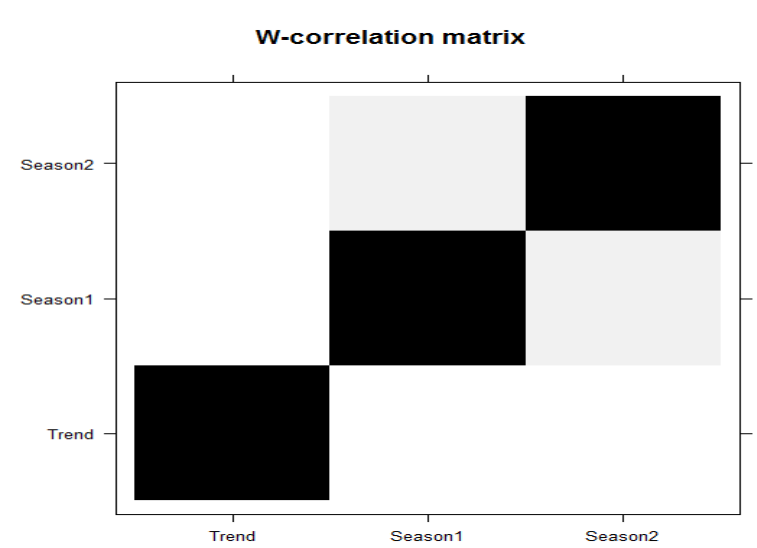

Gambar 4. Matriks korelasi W

\section{Diagonal Averaging}

Pada tahapan ini dilakukan transformasi dari hasil pengelompokan matriks $\mathrm{X}_{\mathrm{Ii}}$ dari penguraian kelompok $\mathrm{X}=\mathrm{X}_{\mathrm{I} 1}+\mathrm{X}_{\mathrm{I} 2}+\cdots+\mathrm{X}_{\mathrm{Im}}$ menjadi series baru dengan panjang N. Hasil dari tahapan ini merupakan matriks komponen dengan dimensi K x N dari data insample yaitu 3 x 64 . Kemudian melalui perhitungan didapatkan rataan diagonal averaging yang ditunjukkan pada hasil output, seperti tampak pada Tabel 1. Deret rekontruksi yang dihasilkan dari elementary grouping ini dinamakan deret rekontruksi elementary.

Tabel 1. Hasil Rataan Diagonal Averaging

\begin{tabular}{|c|c|c|c|c|c|}
\hline \multirow{2}{*}{ No } & \multirow{2}{*}{ Data } & \multicolumn{4}{|c|}{ Rekonstruksi } \\
\cline { 3 - 6 } & & Trend & Season 1 & Season 2 & $\begin{array}{c}\text { Diagonal } \\
\text { Averaging }\end{array}$ \\
\hline 1 & $342.852,4$ & $336.308,3$ & $-1.115,812$ & $7.880,7224$ & $343.073,2$ \\
\hline 2 & $340.865,2$ & $340.281,4$ & $3.313,861$ & $1.173,3090$ & $344.768,6$ \\
\hline 3 & $355.289,5$ & $344.853,8$ & $3.403,205$ & $7.058,4263$ & $355.315,5$ \\
\hline$\ldots$. & & & & & \\
\hline 64 & $775.447,1$ & $781.925,0$ & $-2.675,662$ & $-4.373,2088$ & $774.876,1$ \\
\hline
\end{tabular}

Tahapan selanjutnya adalah melakukan peramalan dari serangkaian model yang dibentuk melalui pemecahan data deret waktu di atas dengan metode SSA. Peramalan ini dimaksudkan untuk meramalkan keadaan perekonomian pada tahun 2017 yang digambarkan melalui nilai PDB Atas Dasar Harga Konstan (PDB Riil) selama triwulan I-IV tahun 2017. Hasil output peramalan PDB dapat dilihat pada Gambar 5.

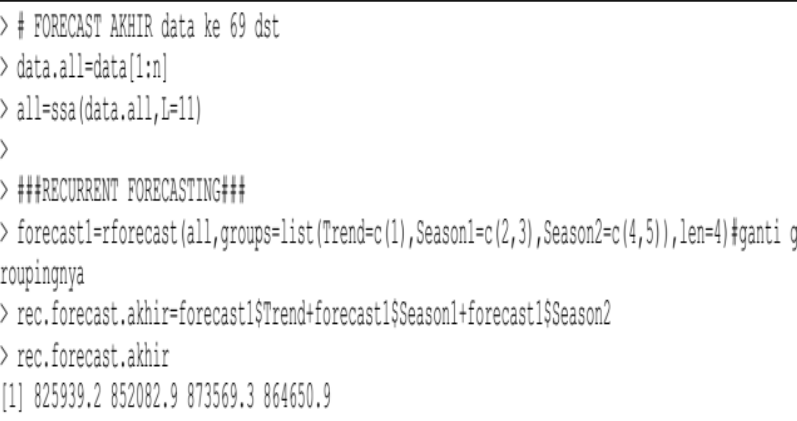

Gambar 5. Hasil Output Peramalan PDB

Dari peramalan PDB Triwulanan Atas dasar Harga Konstan (PDB Riil) melalui metode Singular Spectrum Analysis (SSA) didapatkan ramalan nilai PDB Riil untuk triwulan I (Januari - Maret) 2017 sebesar Rp. 825.939,2 Milyar dan naik menjadi Rp. 852.082,9 Milyar pada triwulan II (April - Juni). PDB Riil triwulan III (Juli - September) naik lagi menjadi 873.569,3 Milyar kemudian mengalami sedikit penurunan pada triwulan IV (Oktober-Desember) ke Rp. 864.650,9 Milyar. Secara total nilai PDB Atas Dasar Harga Konstan 2017 sebesar Rp. 3.416.242,3 Milyar dimana apabila dibandingkan dengan nilai PDB Atas Dasar Harga Konstan 2016 sebesar Rp. 3.218.694,3 Milyar terjadi kenaikan pertumbuhan prekonomian sebesar $6.13 \%$.

Dari model dan hasil peramalan untuk mengukur ketepatan peramalan PDB Riil melalui metode SSA di atas kita menggunakan nilai Mean Squared Error (MSE) dan nilai Mean Absolute Percentage Error (MAPE) melalui syntax pada lampiran 9 bagian akurasi peramalan. Pada metode peramalan SSA dengan window length $\mathrm{L}=9$ dan gruping sebanyak 3 komponen didapatkan nilai berikut (setelah melakukan metode SSA dengan window length yang berbeda dan pengelompokan alternatif nilai yang tertera pada output merupakan pembanding dengan nilai terkecil, seperti tampak pada Gambar 6).

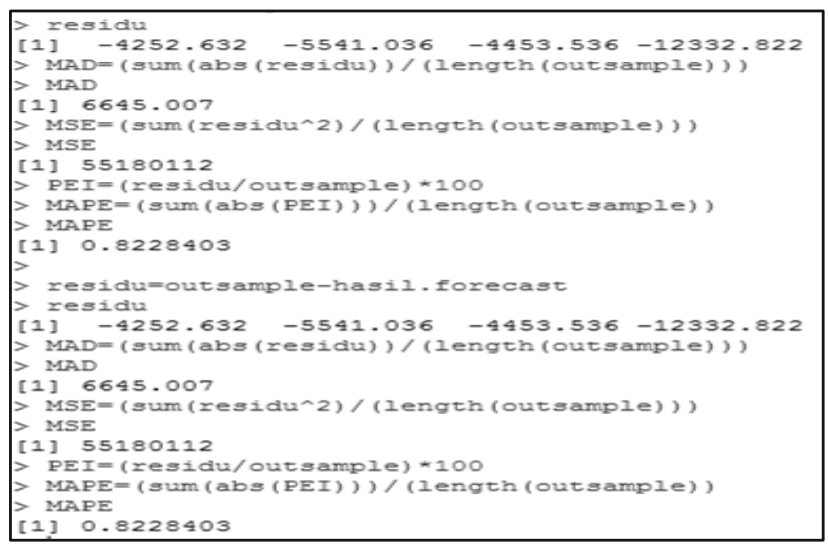

Gambar 6. Hasil Output Pembanding 
Perhitungan menggunakan MAD dan MSE akan menghasilkan nilai yang besar bahkan sampai ribuan, untuk menghindari hal ini maka dapat digunakan alternative nilai MAPE atau Mean Absolute Percent Error, dimana kesalahan dihitung berdasarkan persen kesalahannya absolutenya. MAPE menghitung deviasi antara data aktual dengan nilai peramalan kemudian dihitung persen rataratanya. Adapun nilai MAPE yang dihasilkan cukup kecil yaitu sebesar 0.82 , setelah melakukan beberapa percobaan dengan window length yang berbeda beda dan pengelompokan alternatif maka nilai MAPE ini merupakan nilai yang minimum sehingga diharapkan model peramalan yang terbentuk sudah cukup baik untuk meramalkan nilai PDB Atas Dasar Harga Konstan (PDB Riil) triwulanan tahun 2017.

Setelah mengukur ketepatan model peramalan maka analisis dilanjutkan untuk mengukur validitas peramalan yang diukur menggunakan tracking signal. Apabila nilai-nilai tracking signal berada di luar batas yang dapat diterima yaitu $\pm 5[12]$, maka model peramalan harus ditinjau kembali dan akan dipertimbangkan model baru. Hasil output tracking signal dapat dilihat pada Gambar 7.

\begin{tabular}{cccc}
\hline No & Data Aktual & Predilksi & Tracking Signal \\
\hline $\mathbf{6 1}$ & $779.483,3$ & $785.400,5$ & -0.78 \\
$\mathbf{6 2}$ & $799.738 .$, & $810.897,3$ & -2.25 \\
$\mathbf{6 3}$ & $824.087,1$ & $830.825,5$ & -3.14 \\
$\mathbf{6 4}$ & $815.385,7$ & $821.822,0$ & -4.00 \\
\hline
\end{tabular}

Gambar 7. Hasil Output Tracking Signal

Nilai tracking signal yang terbentuk dari 4 periode peramalan adalah sekitar -4 dimana masih berada dalam batas keandalan peramalan yang dapat diterima, seperti tampak pada Gambar 7. Hal ini dapat diartikan bahwa model peramalan PDB Riil triwulanan Tahun 2017 menggunakan metode SSA merupakan metode yang handal dan dapat dikatakan valid.

\subsection{Bootstrap SSA forecasting}

Confidence Interval atau selang kepercayaan merupakan informasi tambahan tentang keakurasian dan kestabilan peramalan [5, 8]. Dalam menentukan selang kepercayaan dapat digunakan Metode Monte Carlo maupun Metode Bootstrap. Kedua metode ini sangat baik digunakan untuk membandingkan model terbaik dengan metode SSA Recurrent forecasting atau Vector Forecasting.
Pada penelitian ini kita melihat bagaimana hasil peramalan PDB Triwulanan Atas dasar Harga Konstan (PDB Riil) tahun 2017 dan Confidence Interval dengan menggunakan Bootstrap Reccurent Forecasting. Dengan taraf signifikan 95\%, dibangun model menggunakan syntax bootstrap, sehingga dihasilkan output seperti tampak pada Tabel 2.

Tabel 2. Hasil Output Bootstrap Forecasting

\begin{tabular}{ccc}
\hline Hasil Forecast & $\mathbf{2 . 5 \%}$ & $\mathbf{9 7 . 5 \%}$ \\
\hline $827.961,8$ & $822.748,6$ & $833.739,8$ \\
$854.062,4$ & $848.600,5$ & $859.943,3$ \\
$874.484,7$ & $868.779,0$ & $880.453,8$ \\
$866.158,2$ & $860.217,2$ & $872.250,1$ \\
\hline
\end{tabular}

Hasil output pada Tabel 2, menunjukkan bahwa nilai peramalan PDB Riil melalui syntax bootstrap didapatkan ramalan nilai PDB Riil untuk triwulan I (Januari-Maret) 2017 sebesar Rp. 827.961,8 Milyar dengan selang kepercayaan antara 822.748,6 Milyar sampai 833.739,8 Milyar dan triwulan berikutnya (April-Juni) naik menjadi Rp. 854.062,4 Milyar dengan selang kepercayaan antara 848.600,5 Milyar sampai 859.943,3 Milyar. PDB Riil triwulan III (Juli-September) mengalami kenaikan menjadi 874.484,7 Milyar dengan selang kepercayaan antara $868.779,0$ Milyar sampai 880.453,8 Milyar kemudian mengalami penurunan pada triwulan IV (Oktober-Desember) ke Rp. 866.158,2 Milyar dengan selang kepercayaan antara 860.217,2 Milyar sampai 872.250,1 Milyar. Secara total nilai PDB Atas Dasar Harga Konstan 2017 sebesar Rp. 3.422.667,1 Milyar dimana apabila dibandingkan dengan nilai PDB Atas Dasar Harga Konstan 2016 sebesar Rp. 3.218.694,3 Milyar terjadi kenaikan pertumbuhan prekonomian sebesar $6.33 \%$.

\subsection{Perbandingan Hasil Peramalan}

Setelah melakukan seluruh tahapan estimasi, perbandingan antar metode dapat dilihat pada Tabel 3 . 
Tabel 3. Perbandingan hasil peramalan

\begin{tabular}{|c|c|c|c|}
\hline \multirow[b]{2}{*}{$\begin{array}{l}\text { Triwulan } \\
(2017)\end{array}$} & \multicolumn{2}{|c|}{ Nilai Peramalan PDB Rill } & \multirow[b]{2}{*}{$\begin{array}{l}\text { Selang Kepercayaan } 95 \% \\
\text { (Milyar) }\end{array}$} \\
\hline & $\begin{array}{c}\text { Basic Recurrent } \\
\text { (Milyar) }\end{array}$ & $\begin{array}{l}\text { Bootstrap } \\
\text { Recurrent } \\
\text { (Milyar) }\end{array}$ & \\
\hline I & Rp. 825.939,2 & Rp. $827.961,8$ & Rp. 822.748,6 s.d Rp. 833.739,8 \\
\hline II & Rp. 852.082,9 & Rp. 854.062,4 & Rp. 848.600.5 s.d Rp. 859.943,3 \\
\hline III & Rp. 873569,3 & Rp. $874.484,7$ & Rp. 868.779 .0 s.d Rp. $880.453,8$ \\
\hline IV & Rp. $864.650,9$ & Rp. 866.158,2 & Rp. 860.217.2 s.d Rp. 872.250,1 \\
\hline $\begin{array}{l}\text { Pertumbuhan } \\
\text { Ekonomi }\end{array}$ & $6,13 \%$ & $6,33 \%$ & \\
\hline
\end{tabular}

Berdasarkan hasil perbandingan pada Tabel 3, dapat ditunjukkan bahwa nilai peramalan PDB Riil baik menggunakan basic recurrent maupun boostrap recurrent masih berada dalam batas nilai selang kepercayaan dalam tiap triwulan. Nilai pertumbuhan ekonomi yang dihasilkan dengan peramalan bootstrap lebih tinggi dari nilai peramalan basic recurrent, tapi selisihnya sangat kecil. Untuk perbandingan plot data nya bisa dilihat pada Gambar 8.

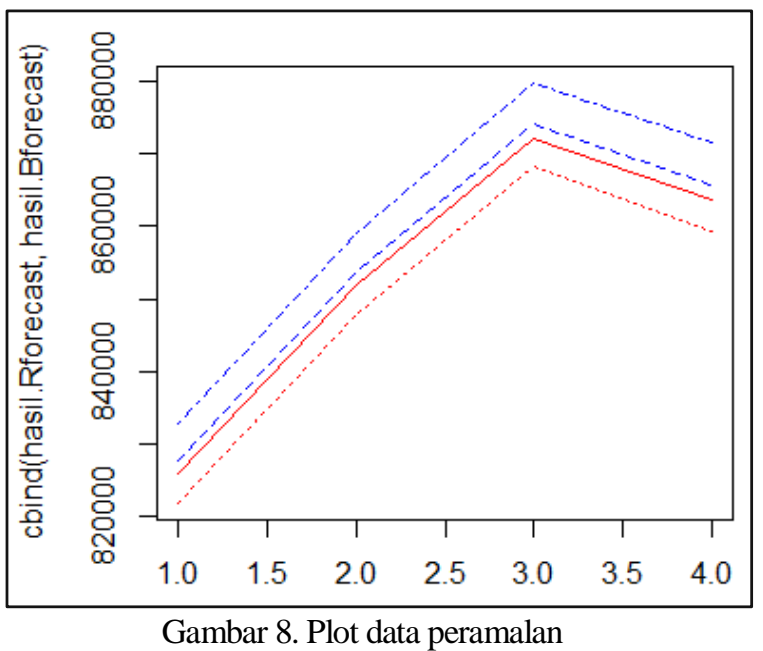

Pada Gambar 8 terlihat jelas plot nilai peramalan PDB Riil dengan menggunakan basic recurrent (berwarna merah) maupun dengan menggunakan boostrap recurrent (berwarna biru) dalam tiap triwulan memiliki fluktuasi yang hampir sama yaitu nilai peramalan PDB naik pada triwulan pertama sampai ketiga kemudian turun pada triwulan keempat.

\section{Kesimpulan}

Berdasarkan hasil dan pembahasan di atas, dapat disimpulkan bahwa PDB Indonesia selama tahun 2000-2006 menunjukkan adanya tren yang meningkat dan dipengaruhi oleh suatu pola musiman. Efek musiman terbesar rata-rata terjadi di setiap triwulan III. Selain itu, berdasarkan peramalan PDB Triwulanan Atas dasar Harga Konstan (PDB Riil) melalui metode Singular Spectrum Analysis (SSA) didapatkan ramalan nilai PDB Riil untuk triwulan I (Januari-Maret) 2017 sebesar Rp. 825.939,2 Milyar dan naik menjadi Rp. 852.082,9 Milyar pada triwulan II (AprilJuni). PDB Riil triwulan III (Juli-September) naik lagi menjadi 873.569,3 Milyar kemudian mengalami sedikit penurunan pada triwulan IV (Oktober-Desember) ke Rp. 864.650,9 Milyar. Secara total nilai PDB Atas Dasar Harga Konstan 2017 sebesar Rp. 3.416.242,3 Milyar dimana apabila dibandingkan dengan nilai PDB Atas Dasar Harga Konstan 2016 sebesar Rp. 3.218.694,3 Milyar terjadi kenaikan pertumbuhan perekonomian sebesar $6.13 \%$ sedangkan dengan menggunakan bootstrap recurrent didapatkan ramalan kenaikan pertumbuhan prekonomian sebesar $6.33 \%$. Terakhir, model peramalan PDB Riil triwulanan tahun 2017 menggunakan metode SSA merupakan metode yang handal dan dapat dikatakan valid dilihat dari nilai ukuran MAPE yang kecil dan ukuran tracking signal pada batas yang dapat diterima.

\section{Referensi}

[1] Prahmana, R.C.I. (2008). Penentuan Harga Opsi untuk Model Black-Scholes menggunakan Metode Beda Hingga Crank-Nicolson. (Skripsi). Yogyakarta: Universitas Gadjah Mada.

[2] Badan Pusat Statistik. (2010). Seasonal Adjustment dan Peramalan PDB Triwulanan. Jakarta: Badan Pusat Statistik.

[3] Darmawan, G. (2016). Identifikasi Pola Data Curah Hujan pada Proses Grouping dalam Metode Singular Spectrum Analysis. Prosiding Sempoa: Seminar Nasional, Pameran Alat Peraga, dan Olimpiade Matematika (pp. 415-424). Surakarta: Universitas Muhammadiyah Surakarta.

[4] Darmawan, G., Hendrawati, T., \& Arisanti, R. (2015). Model Auto Singular Spectrum Untuk Meramalkan Kejadian Banjir di Bandung dan Sekitarnya. Prosiding Seminar Nasional Matematika dan Pendidikan Matematika UNY 2015 (pp. 457-462). Yogyakarta: Universitas Negeri Yogyakarta.

[5] Efron, B., \& Thibshirani, R. (1986). Bootstrap Method for Standar Errors, Confidence Intervals, and Other Measures of Statistical Accuracy. Statistical Science, 1(1), 54-75. 
[6] Golyandina, N., \& Korobeynikov, A. (2012). Basic Singular Spectrum Analysis and Forecasting with $R$. Rusia: Faculty of Mathematics and Mechanic, St. Petersburgh State University.

[7] Golyandina, N., \& Zhigljavsky, A.A. (2013). Singular Spectrum Analysis for Time Series. New York: Springer.

[8] Golyandina, N., Nekrutkin, V., \& Zhigljavsky, A.A. (2001). Analysis of Time Series Structure: SSA and Related Techniques. New York: Chapman \& Hall/CRC.

[9] https://bps.go.id/Subjek/view/id/11\#subjekViewTa b3|accordion-daftar-subjek1.

[10] Leeuw, J.D., \& Crutcher, P. (2009). Singular Spectrum Analysis in R. Los Angeles: Department of Statistics, University of California.

[11] Sungkawa, I., \& Megasari, R.T. (2011). Penerapan Ukuran Ketepatan Nilai Ramalan Data Deret Waktu dalam Selesi Model Peramalan Volume
Penjualan PT Satria Mandiri Citra Mulia. Jakarta: Departemen Matematika dan Statistik, Universitas Binus.

[12] Abraham, B., \& Ledolter, J. (1983). Statistical Methods for Forecasting. New York: John Wiley.

[13] Darmawan, G., Handoko, B., \& Suparman, Y. (2016). Seasonal Test for Non-Stationary Time Series Data by Means of Periodogram Analysis. Prosiding the $2^{\text {nd }}$ International Conference on Applied Statistics (pp. 74-81). Bandung: Fakultas Matematika dan Ilmu Pengetahuan, Universitas Padjajaran.

[14] Prahmana, R.C.I. (2017). Design Research (Teori dan Implementasinya: Suatu Pengantar). Jakarta: Rajawali Pers. 